\title{
TNF-a Production Inhibitory Activity Measurement
}

National Cancer Institute

\section{Source}

National Cancer Institute. TNF-a Production Inhibitory Activity Measurement. NCI

Thesaurus. Code C117862.

The determination of the amount of TNF-alpha production inhibitory activity present in a sample. 